\title{
Evaluation towards Foreign Direct Investment (FDI) in Indonesia and Its Relation with Democracy after 20 Years of the Collapse of Orde Baru
}

\author{
Ferdian Ahya Al Putra ${ }^{1}$, Randhi Satria S.IP, M.A ${ }^{2}$ \\ ${ }^{I}$ Student of International Relations Department, Faculty of Social and Political Sciences, Universitas Sebelas Maret, Jl Ir \\ Sutami No. 36A, Surakarta, Indonesia. \\ ${ }^{2}$ Department of International Relations, Faculty of Social and Political Sciences, Universitas Sebelas Maret, Jl Ir Sutami No. \\ 36A, Surakarta, Indonesia. \\ putraferdie@gmail.com, ransatria@staff.uns.ac.id
}

Keywords: International cooperation, democracy, capitalism, social and culture.

\begin{abstract}
Since the monetary crisis and reformation in 1998, Indonesia has developing to be a democratic country. The direction of the economic system in Indonesia has led to capitalism where the Foreign Direct Investment (FDI) entered Indonesia and influenced the International cooperation in the country. The matter is important to be discussed since FDI influenced Indonesia's economic system. The purpose of this research is to analyze the policy related to the FDI since the collapse of Orde Baru and how democracy can influence the decision making process regarding FDI. This issue is analyzed using Political Risk and Liberalism Theory. This research is also using descriptive qualitative method are used to analyze the issue. To obtain the data, the writers were using literature study by collecting the data and facts from Online Journal, Official Sites, Books, and internet article. From the result, we can find that the growth of FDI in Indonesia has reached 13.2 percent in the first quartile of 2017 and absorbed 164.000 labors. However, this number was dominated by foreign investors. The latter also influenced the competition towards Small-Medium Enterprises in Indonesia and changed the social and cultural sector where the society grew more consumptive.
\end{abstract}

\section{INTRODUCTION}

It has been 20 years since the collapse of Orde Baru in Indonesia that transforms the governance and economic system and leading Indonesia to be a democratic country and more liberal in the economic system. After the monetary crisis and reformation in 1998, development becomes the main goal of Indonesian government in order to achieve national welfare. In developing the economy, the Indonesian Government implemented democratic economy through attracting the Foreign Direct Investment (FDI) to gain as much capital as possible. FDI refers to International capital flow where an enterprise can establish or expand its business in a foreign country (host country). The action is not only about the movement of resources, but also to gain control towards overseas companies (Krugman, 1992). This was usually applied by a company through capital investment to another company in a foreign country.

FDI in Indonesia is implemented by considering the political risk in the country. The investment will be easier to gather when the political risk in Indonesia is low, which also means that there is a low limit for the transfer risk of capital. Based on the data released by Investment Coordinating Board (Badan Koordinasi Penanaman Modal, BKPM), the number of FDI in Indonesia has reached 165,8 thousand billion Rupiah in the first quartal of 2017. This number has increased $13.2 \%$ more than the previous year with the total of $146.5 \%$. Furthermore, the investment was absorbing around 194.000 labors (Setiawan, 2017).

The data has proven that Indonesia's economic system is going to be global. In this case, the National 
government welcomed the FDI in order to develop the country as a response to the transformation in the economic and political system. Historically, during the monetary crisis, Indonesia was given a loan from the International Monetary Fund (IMF). As one of its duty is to restore the country's economy, IMF "coerced" Indonesia to change their economic system to be more flexible. It can be seen from the event where Soeharto signed the Letter of Intent (LoI) proposed by IMF (Habibi, 2009). It was then resulting in Indonesia's market to be more flexible in allowing the flow of FDI.

The entry of the FDI in Indonesia give impacts to the developmental capital support and absorbing the unemployment, but on the other hand, the entry of the FDI also impacts the local enterprises in Indonesia. Through FDI, the market is dominated more by foreign investors. As a result, the society tends to be more consumptive on the foreign product. Moreover, the situation is transforming Indonesian social and cultural sector. The society started to neglect traditional markets to move towards the modern market that consists of foreign goods as the result of FDI. Finally, the local entrepreneurs cannot compete with foreign goods and services. This also transforms the society pattern as shown by cultural degradation.

According to the explanation above, the writers would like to analyze the policy of Foreign Direct Investment (FDI), the democracy after 20 years since the collapse of Orde Baru, and its impact towards the social and cultural sector in Indonesia. This matter is important to be discussed since it can influence the development and society pattern in Indonesia.

\section{METHODS}

\subsection{Descriptive qualitative method}

This paper will explain the issue with explanatory descriptive research. According to Mely G. Tan, descriptive research has a purpose to describe characteristics of an individual, a phenomenon, and the connection frequency between one symptom and another in a society. Descriptive research also focused on the question of how and to later explain it by delivering the facts clearly, thoroughly, and completely (Sillalahi, 2009). The data obtained in the qualitative research refer as empirical data in the form of tangible words instead of series of numbers. It cannot also be arranged in categories/structure classification (Sillalahi, 2009).

\subsection{Political risk}

Political risks can be divided into three basic categories: transfer risks, operational risks, and ownership-control risks. Transfer risk refers to the Government's policy to restrict capital transfers, payments, production, people, and technology in the domestic and international market. The examples include tariffs on exports and imports, restrictions on exports, dividend remittance, and capital repatriation (Luthans \& Doh, 2012). Operational risk resulted from the Government policies and procedures that directly constrain the management and performance of local operations. The examples include price controls, financing restrictions, export commitments, taxes, and local sourcing requirements. Ownership-control risk is embodied in the Government policies or actions that inhibit the ownership or control of local operations. The example includes foreign ownership limitations, pressure for local participation, confiscation, expropriation, and abrogation of proprietary rights. (Luthans \& Doh, 2012).

\section{RESULT AND DISCUSSIONS}

The transformation of the political and economic system in Indonesia cannot be separated from the country's historical background. The monetary crisis that in Indonesia has pushed the emergence of the social movements that can pressure the government. This situation led Indonesia to be more democratic and also gave an impact on the economic system where the capital and private ownership were appropriately recognized with the liberalist-capitalism concept. A state is not the only actor in International Relations. An individual and private actors also have significant roles within the International Relations. They have an assumption that every person is kind and able to be cooperative (Jackson \& Sorensen, 2013). On the other hand, John Locke explained that the state exists to guarantee the freedom of their society. The state let them live their lives and reach their happiness without any interference from another party (Kurniawan, 2011). 
Liberalism recognized an individual's freedom. It can be explained through guaranteed freedom of expression which led to a democratic political system. The citizen must be involved in the decision-making process to facilitate the democracy. In the economic sector, however, Adam Smith explained that there must be a presence of self-interest which is defined as a power to control the economy. All the running process will lead to National prosperity as if every individual was driven by an "invisible hand" that pushed them forward (Dahar, 2012).

The transfer risk of Indonesian Government can be seen from the regulations that they had implemented relating to the FDI. The FDI related policy has been released since the 1967 through Regulations No. 1/1967 about Foreign Investments. But, since the transformation of the economic and political system in Indonesia happens after the collapse of Orde Baru, this policy was assumed not to be any more relevant. The government has issued a new policy then, by publishing Regulations No. 25/2007. This policy was issued to fulfill the aim of article 33 in the third paragraph of UUD 1945, which is to create a democratic economy that prioritizes Indonesian citizen's interest and welfare as the base of the National economy.

The democratic country believes that to accelerate the economic development as well as to create the political and economic sovereignty. The increase of investment is important in order to develop the economic potential into an economic power by using capital from both domestic and foreign investment as mentioned in UU No. 25/2007. Moreover, the establishment of Peraturan Presiden No. 26/2016 about the List of Closed Business Fields and Open Business Fields with Requirements in the Field Of Investment. The transfer risk can be classified as low or high by looking at the number of investment annually. According to the data released by Central Statistics Body (Badan Pusat Statistika, BPS), the number of foreign investment has increased annually. As the example, after UU No. 1 25/2007 was issued, Indonesia's foreign investment has reached US\$ 1.138 million. In 2016, the foreign investment has reached US\$ 25.321 million (BPS, 2017). It can be seen that the transfer risk of FDI in Indonesia is considered low or not strict, meaning that foreign investment can enter Indonesia easily. This resulted in the widespread of products from foreign enterprises or MNCs in Indonesia.
Singapore has become Indonesia's biggest investor during the period of January-September 2017. Despite a declining report of 14 percent in the third quartile, Singapore's investment in Indonesia is still the biggest. The data gained from the Investment Coordinating Board (BKPM) noted that the Foreign Direct Investment (FDI) originated from Singapore from January-September 2017 period fell to US\$ 6.12 billion (Rp 82.6 trillion). From the same period in the previous year, it reached US\$ 7.13 billion (Katadata, 2017). These are the top ten of investor in Indonesia in 2017 depending on the country (Katadata, 2017).

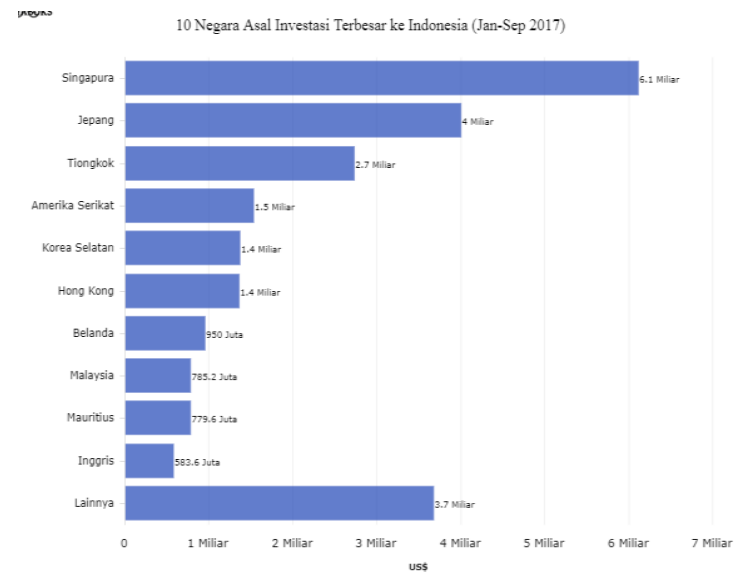

Figure 1: 10 Countries with the Biggest Investment in Indonesia 2017 (January-September)

\subsection{The connection of FDI and democracy in indonesia}

The government is aware that Indonesia is a democratic country. The latter makes people participation is much needed for the development. The participation is expected to reach every layer of society in Indonesia, especially the grass-root society. The government, however, also need capitals for the development. They can gather the foreign capital to decrease the unemployment rate, depending on the conditions. The reduction also refers to the improvement of people's participation in the development.

As it influenced the National welfare, his situation can develop Indonesia's economy further. The capital, however, has not been evenly distributed. The latter 
can cause another capital flow domination in Indonesia by the foreign investors. Moreover, the investments are mostly focused on the manufacturing sector. This situation can widen the economic gap between the foreign investors and local enterprises. Finally, the need for the capital can created dependency towards the foreign capital. This condition is harmful for the state income as the result of the development couldn't be absorbed entirely.

In order to create a balance, the Government developed a concept of Ekonomi Kerakyatan or People-centered Economy. In the economic study, People-centered Economy is also known within the concept of One People One Product, One Village One Product, and One Village One Cooperation/Koperasi (OPOP-OVOP-OVOC). This kind of economic system is implemented through the establishment of Koperasi. Koperasi is a legal-based institution that accommodates people's capital and helps them to market their products at the local level of enterprise.

Therefore, it can be mentioned that without people's democratic participation, FDI will create Foreign Capital dependency. By balancing the FDI and the democracy, the people's participation in the development will increase, as well as their productivity. A new problem arises when Indonesia is not yet ready to be economically independent. Human resources are one of the factors that influence this situation. In conclusion, the FDI is also needed in order to facilitate the transfer of knowledge through workshops or training for the labor force that can be implemented through Corporate Social Responsibility (CSR).

Based on Sri-Edi Swasono's statement, Indonesia's Democratic Economy has two principles as its base. The principles are participation and emancipation. They are aimed at liberating the National economy from exploitation, discrimination, and dependency. The connection between FDI and Democracy in Indonesia can be found through the implementation of People-centered Economy in Small-Medium Enterprises. As the FDI also needs capital, this will create a competition between the foreign investor, private sectors, and SMEs.

Independent economy will be hard to be achieved as long as Indonesia is still dependent on foreign investments. The People-centered Economy concept will be harder to develop if the FDI keep gaining more capital. Democratic Economy in Indonesia is the antithesis towards the dependency of foreign capital.
In this situation, the Government needs to increase the political risk relating to the restriction of foreign investment.

In more complex situations, the democratic process in Indonesia is highly influenced by the foreign investment. Demonstrations as a form of democratic process has a potential to decrease foreign investments. As stated by the chief executive of Schroder, an Investment Manager Enterprise, Michael $\mathrm{T}$ Tjoajadi demonstrations, even without violence have already gained a negative stigma, moreover if the demonstration grows violent. It can certainly affect the share fluctuations that is reflected in the Composite Share Price Index (IHSG) (Okezone, 2016).

The widespread labor demonstration in some Indonesian cities has begun to affect the investment. Due to the labor demonstrations, US\$ 20 billion, equivalent to 190 trillion Rupiah is claimed to be at loss. Apindo also suggested relocating at least 10 companies that will drop US\$ 100 million worth of investment. One hundred companies from 23 associations also threatened to stop their production. The condition clearly worsened the investment climate (Kompas, 2012).

\subsection{Democracy, media, and technology advancement}

The media has become a major instrument that has a significant role to facilitate the democratic process in Indonesia. After the collapse of Orde Baru, the Government guaranteed the freedom of expression. This situation is enabling the people to show their political opinions through the media. The media also has a function to shape public opinions hence they must be objective by covering both sides of a story.

The advancement of the technology and information sector has also influenced the International cooperation in Indonesia. The latter can be seen from the emergence of the Multinational Corporations (MNCs). The transition in the form of modern mass media became the main factor in the existence of Multinational Corporations. Currently, the media is not only used to spread the news but also can be a place to set up an advertisement. As a result, the media has an important role in influencing the consumer to buy imported products/brands.

The technology advancement in Indonesia is supported by the Government policy in order to create 
a condition where imported products, such as smartphones can be sold at a lower price. This resulted in the high level of technological consumption in almost every layer of Indonesian. They became more liberal in sharing opinions closely related to the political issue. This became a problem when the people easily accept the information from a single source only. Not all of information from media is relevant with the real condition in the field, therefore the Government has new responsibility in preventing false information or hoax.

In this modern era, contemporary democratic society has emerged. This could not be separated from the social media development, where in Indonesia it mostly influenced by International cooperation. The use of smartphones and easy internet access has improved the democratic process through social media. This situation could be seen during the General Election in 2014. Each party and Presidential Candidate were using social media to promote their campaign. Through the action, we can see that the people's participation in the democratic process has increased. However, by using the social media, they have to face the consequence of black campaign. This can result in the decreasing quality of democracy in Indonesia and should be evaluated.

\subsection{Economic and social-cultural impact}

The transformation within the political and economic system in Indonesia has brought impacts to the economic and social-cultural sector. The first notable impact of the foreign investment in Indonesia can be seen from the development of facilities and infrastructures in many regions of Indonesia. These developments are supported by the fluent economic activity that led domestic enterprises development. They gained foreign investment that will also influence the emergence of MNCs and economic growth in Indonesia. The increasing economic growth in Indonesia is predicted to reach 5.6\% in 2018 as it is supported by investors and society's consumption level (Muthmainah, 2018). Moreover, the FDI and MNCs in Indonesia absorbs more labor and can reduce the unemployment rate. According to the data released by Central Statistics Body (BPS), the FDI is increasing at the number of $3.4 \%$ or around 111.7 thousand billion Rupiahs. It also absorbs the labors up to 286.000 people (Tamara, 2018). From the data, it was proven that FDI is dominating the capital flow in Indonesia.

Both the FDI and MNCs in Indonesia are contributing to the transformation of Indonesian society's pattern. Nowadays, the society tends to consume imported products, varying from electronic gadgets such as Lenovo to branded clothing line such as Adidas and Nike. All of them are the products from foreign MNCs. There are no significant differences between the imported products and the local. The society consumes that brands as a form of prestige. The Vice Governor of Central Java, Heru Sudjadmoko, also mentioned that most of the society felt like foreign products are better and more prestigious than the local (Movanita, 2015). This tendency brings the society to look up to the foreign culture that can cause cultural degradation in Indonesia. This is one of the effects or manifestation of economic liberalization where trade barriers are eliminated to create a borderless world. The effect also caused the disappearance of traditional markets. The cultural transfer as the result of the existence of MNCs in Indonesia had transformed the society to stop buying local products. Eventually, this climate can create an economic gap between the local and foreign entrepreneurs. It is also against with TAP MPR XVI/ MPR/1998 Regulation on Political Economy within the Economic Democracy framework. In order to prevent the harmful effect, the Government has to manage the transfer risk policy, which means that they have to limit capital flow, especially from the foreign investment. According to the explanation above, the research produces the following scheme.

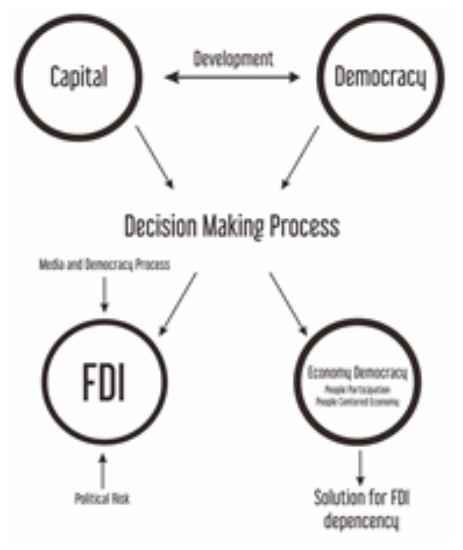

Figure 2: Relation between FDI and Democracy toward International Cooperation 


\section{CONCLUSION}

According to the explanations above, the entry of FDI in Indonesia could not be separated from the historical background. Both the growth of FDI and MNCs in Indonesia impacted the domestic situation in the country in three aspects. First, an economic advantage. The aim of FDI is to gain more capital and absorb the unemployment rate. The application can increase the state's income, especially from the tax sector. On the other hand, this will also threaten the democratic economy concept in Indonesia. Second, FDI can affect the social-cultural aspect. Through the Foreign investment, the society tends to be more consumptive. To tackle the dependency towards foreign capitals, democratic economy must be applied in order to increase the people's participation in development, most importantly to reduce the unemployment rate. The policy related to the FDI and democratic economy must have a long discussion within the parliament with the fact that showed FDI as a more popular way to gain capital for development. It can be seen from the number of the FDI per year. The democratic process has a major role in influencing the International cooperation in Indonesia, although it still depends on the climate of democracy. Another important point is to reconsider the political risk in the Parliament.

Regarding the conclusion above, the writer suggests solutions related to the situations. First, strengthen the policy to control the flow of the FDI in Indonesia to protect the local enterprises. Second, develop the microeconomic sector to reduce the dependency on foreign investor (One People One Product, One Village One Product, and One Village One Cooperation). Third, improve the quality of democracy in order to facilitate a better development.

\section{REFERENCES}

BPS. (2017, November 24). Realisasi Investasi Penanaman Modal Luar Negeri Menurut Provinsi 1 ( juta US\$), 2006-2016. Retrieved May 18, 2018, from bps.go.id: https://www.bps.go.id/statictable/2014/09/17/1337/realis asi-investasi-penanaman-modal-luar-negeri-menurutprovinsi-sup-1-sup-juta-us-2006-2016.html

Dahar, R. (2012). TEORI INVISIBLE HAND ADAM SMITH. Jurnal Economica, 57-70.

Habibi, M. (2009). Gemuruh Buruh di Tengah Pusaran Neoliberalisme. Yogyakarta: Gava Media.
Jackson, R., \& Sorensen, G. (2013). Pengantar Studi Hubungan Internasional. New York: Oxford University Press, Inc.

Katadata. (2017, December 1). Inilah 10 Negara dengan Investasi Terbesar ke Indonesia 2017. Retrieved August 11, 2018, from katadata.co.id: https://databoks.katadata.co.id/datapublish/2017/12/01/in ilah-10-negara-dengan-investasi-terbesarke-indonesia2017

Kompas. (2012, November 28). Demonstrasi Buruh dan Perjanjian Investasi. Retrieved August 1, 2018, from kompas.com:

https://nasional.kompas.com/read/2012/11/28/04584498/ demonstrasi.buruh.dan.perjanjian.investasi

Krugman, P. R. (1992). Ekonomi internasional: teori \& kebijakan. Jakarta: Rajawali Press.

Kurniawan, R. C. (2011). Global Governance: Perspektif Liberalisme. Jurnal FISIP UNBARA Volume 4, Nomor 8, Desember 2011, 1-7.

Luthans, F., \& Doh, J. P. (2012). International Management: Culture, Strategy, Behaviour. New York: The McGrawHill Companies, Inc.

Movanita, A. N. (2015, October 15). Masyarakat Lebih Menyukai Produk Impor karena Gengsi. Retrieved April 22, 2018, from kompas.com:

https://ekonomi.kompas.com/read/2015/10/15/19180072 6/Masyarakat.Lebih.Menyukai.Produk.Impor.karena.Ge ngsi

Muthmainah, D. A. (2018, March 5). Ekonomi Indonesia Diramal Tumbuh 5,6 Persen Tahun Ini . Retrieved April 22, 2018, from cnnindonesia.com: https://www.cnnindonesia.com/ekonomi/201803051939 59-532-280675/ekonomi- indonesia-diramal-tumbuh-56persen-tahun-ini

Okezone. (2016, November 25). Demonstrasi Pengaruhi Pemodal Melakukan Investasi Saham. Retrieved August 1, 2018, from okezone.com: https://economy.okezone.com/read/2016/11/25/278/1551 409/demonstrasi-pengaruhi-pemodal-melakukaninvestasi-saham

Raharjo, M. Dawam (2012). Pembangunan Pascamodernis. Yogyakarta: INSISTPress.

Setiawan, S. D. (2017, April 26). Kuartal I 2017, Realisasi Investasi di Indonesia Capai 165,8 Triliun. Retrieved April 8, 2018, from https://ekonomi.kompas.com/read/2017/04/26/15252692 6/kuartal.i.2017.realisasi.investasi.di.indonesia.capai.165 .8.triliun

Sillalahi, U. (2009). Metode Penelitian Sosial. Bandung: PT. Refika Aditama.

Tamara, N. H. (2018, January 12). Investasi Naik, Pengangguran Turun? Retrieved April 22, 2018, from katadata.co.id: https://databoks.katadata.co.id/datablog/2018/01/12/inve stasi-naik-pengangguran-turun 